\title{
Pengembangkan Kompetensi Mahasiswa Jurusan Bimbingan Konseling Islam melalui Peningkatan Laboratorium Konseling
}

\author{
Jaja Suteja
}

\begin{abstract}
Abstrak
Setiap Perguruan Tinggi harus memiliki Standar Pendidikan Nasional di dalam memaksimalkan kompetensi mahasiswa yang meliputi; Standar Isi, Proses, Kompetensi Lulusan, pendidik dan tenaga kependidikan, sarana dan prasarana, pengelolaan, pembiayaan dan penilaian. Salah satu upaya dalam memaksimlakan kompetensi mahasiswa yaitu dengan adanya laboratorium sebagai penunjang dalam menggali ilmu pengetahuan dan mengembangkan skill atau keterampilan konseling mahasiswa. Kondisi rill saat ini Jurusan BKI belum memiliki sarana laboratorium konseling, di dalam mengembangkan skill mahasiswa padahal sudah hampir 4 (empat) tahun jurusan BKI ini berdiri di Kampus IAIN Syekh Nurjati Cirebon. Saat ini, baik mahasiwa maupun dosen yang mengajar di Jurusan BKI sudah sangat membutuhkan tempat laboratorium sebagai tempat Praktikum Kuliah mahasiswa. Dalam penelitian ini pendekatan yang digunakan oleh peneliti adalah pendekatan kualitatif/naturalistik dengan sumber datanya diambil dari respon mahasiswa, dosen BKI dan pimpinan Fakultas Ushuluddin Adab dan Dakwah. Sedangkan teknik pengumpulan datanya melalui kegiatan observasi partisipan, wawancara mendalam dan studi dokumentasi. Kesimpulan dari penelitian ini menunjukkan bahwa mahasiswa BKI saat ini sangat membutuhkan laboratorium konseling BKI, oleh karena itu untuk terwujudnya laboratorium konseling yang berkualitas dibutuhkan perhatian dan dukungan dari semuanya baik itu dari lembaga, fakultas maupun dosen-dosen yang ada di jurusan Bimbingan Konseling islam.
\end{abstract}

Kata Kunci: Kompetensi, BKI, Laboratorium, Konseling

\section{PENDAHULUAN}

Perkembangan ilmu pengetahuan, teknologi informasi dan komunikasi yang sedemikian pesat, menyebabkan berubahnya berbagai kebutuhan SDM di berbagai bidang keilmuan, termasuk di dalamnya pengembangan program studi di perguruan tinggi. Pada saat suatu program studi mengembangkan tujuan pembelajaran yang merupakan titik akhir proses, didasarkan pada standar isi, maka prodi tersebut akan cepat tertinggal oleh pasar kerja. Hal ini disebabkan bahwa peran SDM di suatu perkerjaan pun mengalami perubahan, teknologi dan cara pengerjaannya mengalami perubahan yang sangat drastis. 
Hal inilah yang memperpanjang kesenjangan antara penyedia SDM dalam hal ini perguruan tinggi dengan pasar kerja yang memerlukan SDM. Untuk menyiapkan SDM yang profesional dan dapat diserap oleh dunia kerja dibutuhkan pengembangan kurikulum yang dinamis dan kekinian serta sarana dan prasarana yang mendukung di dalam peningkatan skill dan kompetensi mahasiswa.

Perguruan Tinggi memiliki peran sentral bagi upaya penyiapan sumber daya manusia unggul. Menurut Ditjen Dikti (2003) perguruan tinggi di Indonesia memiliki peran yang sangat penting, baik sebagai sumber pengembang dan pemanfaatan ilmu pengetahuan maupun sebagai penghasil lulusan. Dengan demikian, agar perguruan tinggi tidak tertinggal atau ditinggal peserta kuliahnya maka dibutuhkan keseriusan perguruan tinggi di dalam pengembangan kurikulum dan melengkapi sarana dan prasarana yang dapat menunjang kemampuan dan keterampilan mahasiswa.

Berdasarkan pertimbangan tersebut, perlu kiranya setiap lembaga perguruan tinggi melakukan penataan ulang dari aspek internal maupun dari aspek eksternal. Dari aspek internal di antaranya melakukan penataan kelembagaan, penataan arah dan tujuan pendidikan serta penataan pengelolaan program studi itu sendiri. Sedangkan pada tataran eksternal, perguruan tinggi harus mampu menghadapi persaingan global, perubahan kebutuhan dan persyaratan kerja, serta perubahan orientasi dalam pengelolaan lembaga perguruan tinggi sesuai dengan kurikulum berbasis KKNI (Said Hasan Basri, 2014).

Untuk menciptakan pendidikan yang berkualitas di dalam sebuah perguruan tinggi diperlukan pedoman yang sesuai dengan Standar Sistem Pendidikan Nasional antara lain meliputi ; standar isi, standar proses, standar kompetensi lulusan, standar pendidik dan tenaga kependidikan, standar sarana dan prasarana, standar pengelolaan, standar pembiayaan dan standar penilaian pendidikan (Direktorat Tenaga Kependidikan Ditjen Peningkatan Mutu Pendidikan, 2008).

Berkaitan dengan masalah tersebut, Jurusan Bimbingan Konseling Fakultas Ushuludin Adab dan Dakwah IAIN Syekh Nurjati Cirebon, dituntut untuk senantiasa melakukan revisi kurikulum dan melengkapi sarana prasarana yang ada di dalam peningkatan standar mutu dan kualitas secara totalitas sesuai dengan amanat Badan Standar Nasional Pendidikan (BSNP). Oleh sebab itu, untuk menjawab tantangan perubahan baru tersebut di dalam peningkatan standar mutu khususnya di kalangan mahasiswa BKI, paling tidak mahasiswa dibekali tidak hanya kemampuan teoritis melainkan kemampuan praktis di dalam meningkatkan skill dan kompetensinya.

Jurusan Bimbingan Konseling Islam sebagai salah satu jurusan yang baru terbentuk di perguruan tinggi agama Islam, sangat merespon adanya perubahan paradigma pendidikan dari mulai input, output sampai out come bagi mahasiswanya. Hal ini dibuktikan dengan banyaknya perubahan mulai dari penataan kurikulum, kelengkapan administrasi, kegiatan mahasiswa dan minat yang tinggi mahasiswa baru untuk masuk ke Jurusan Bimbingan Konseling Islam. 
Dalam upaya mempersiapkan mahasiswa BKI yang memiliki ilmu pengetahuan dan keterampilan khususnya dalam bidang bimbingan (penyuluhan) dan konseling dibutuhkan kurikulum dan sarana laboratorium konseling yang menunjang di dalam penguatan kompetensi mahasiswa. Sebagaimana diketahui bahwa laboratorium merupakan sebuah tempat yang dilengkapi mulai dari sarana kantor, ruangan konseling, ruangan bimbingan dan sebagai media mahasiswa di dalam melakukan percobaan-percobaan yang terkait dengan bidang bimbingan dan konseling. Selain itu, dengan adanya laboratorium menjadikan mahasiswa jauh lebih siap dan mandiri dalam mengembangkan bakat dan minatnya sesuai dengan apa yang dicita-citakan (Jaja Suteja, 2013).

Setelah menyelesaikan studi di jurusan Bimbingan dan Konseling Islam ini, para alumninya secara teoritis diharapkan dapat memahami dan menguasai berbagai konsep tentang Bimbingan dan Konseling Islam, serta memiliki kapasitas intelektual untuk memahami masalah-masalah psikologis individu, kelompok (komunitas) dan masyarakat luas. Pada level praktis, kompetensi mahasiswa di jurusan BKI diharapkan mampu mengidentifikasi dan menyelesaikan masalahmasalah psikologi dalam keluarga dan masyarakat, melalui penyelenggaraan bimbingan dan konseling Islam, pemberian motivasi dan pelatihan, serta tindakan mediasi dan advokasi (A. Said Hasan Bashri, 2014).Di dalam proses perkuliahan, sangat jarang mahasiswa dapat memahami mata kuliah dengan benar secara kontinyu ketika proses pembelajarannya hanya dilaksanakan di bangku kuliah. Dalam memahami pembelajarannya, mahasiswa tidak cukup mengetahui, ataupun menghafal materi kuliah, karena biasanya hal tersebut belum bersifat kongkrit. Akan tetapi mahasiswa diperlukan sebuah tempat yang kongkrit di dalam proses pembelajarannya terutama dalam mengggali, menguji coba, maupun mempraktekkannya secara langsung baik bersama dengan dosennya maupun dengan sesama mahasiswanya. Tempat yang paling cocok dan pas untuk mempraktekkan dan mengujicobakan semua materi kuliah yang berbasis praktikum yaitu laboratorium.

Keberadaan laboratorium sebagai tempat praktek mahasiswa dalam memaksimalkan kompetensinya, dirasakan sangat penting di dalam proses pembelajaran. Di setiap proses perkuliahan khususnya mata kuliah yang menekankan pada kegiatan praktikum, seyogyanya dapat dilaksanakan di pusat laboratorium konseling BKI. Selain itu, keberadaan laboratorium juga dapat dijadikan sebagai tempat uji coba baik oleh dosen maupun mahasiswa di dalam mengimplementasikan materi secara teoritis dengan membuktikan secara langsung paktisnya melalui pusat laboratorium BKI.

Selain itu, kebutuhan laboratorium ini tidak hanya dalam upaya menyiapkan mata kuliah keilmuan yang berbasis teoritis tetapi dalam upaya menyiapkan kurikulum muatan mata kuliah yang berbasis keterampilan atau praktik. Setiap dosen yang mengampu mata kuliah praktikum bimbingan konseling tidak hanya menekankan pada aspek keilmuan teoritis, tetapi harus ditekankan juga kemampuan 
praktisnya yaitu dengan cara melakukan praktik konseling di dalam ruang perkuliahan, melakukan observasi ke sekolah-sekolah yang memiliki ruangan konseling dan melakukan kegiatan konseling langsung ke masyarakat, walaupun dirasakan oleh mahasiswa belum maksimal.

Mahasiswa BKI ke depan harus melaksanakan kegiatan PPL (Praktik Pengalaman lapangan) ke Sekolah, Industri, Pusat Terapi, Rumah Sakit, Lembaga/Institusi Pemerintah, dan tempat-tempat lainnya yang menuntut mahasiswa paham dan menguasai tidak hanya secara teoritis tetapi juga secara praktik di dalam memaksimalkan kompetensinya. Tanpa adanya sebuah laboratorium konseling maka kompetensi mahasiswa BKI akan lemah dari sisi keterampilan konseling, oleh karena itu keberadaan laboratorium bagi mahasiswa BKI tingkat kebutuhannya sangat vital dan mendesak.

Dalam proses pendidikan, kompetensi itu adalah sesuatu yang mutlak yang harus dijadikan standar oleh masing-masing peserta didik. Menurut teori belajar kognitivisme, menyatakan bahwa proses belajar yang dilakukan oleh peserta didik harus meliputi kemampuan psikis atau mental manusia yang berupa mengamati, melihat, menyangka, memperhatikan, menduga, dan menilai. Menurut teori kognitif, menyatakan bahwa proses belajar terjadi karena ada variable penghalang pada aspek-aspek kognisi seseorang. Belajar tidak hanya sekedar melibatkan hubungan antara stimulus dan respon, bahwa lebih dari itu belajar melibatkan proses berfikir yang sangat kompleks (S. Hall Calvin, Lindzey Gardner, 1993).

Gagne, dalam bukunya menyebutkan bahwa belajar adalah sesuatu yang kompleks. Setelah belajar orang memiliki keterampilan, pengetahuan, sikap dan nilai. Dengan demikian belajar adalah seperangkat proses kognitif yang mengubah sifat stimulus lingkungan melewati pengolahan informasi, menjadi kafabilitas baru. Dalam teori ini menunjukkan bahwa belajar tidak hanya cukup mengetahui pengetahuan teoritis melainkan harus diimlementasikan dalam praktis melalui berbagai kegiatan keterampilan (R.M. Gagne \& Medsker K. L, 1996).

Secara teoritis, adanya laboratorium konseling bagi mahasiswa BKI dijadikan tidak hanya sebagai tempat belajar menggali ilmu bagi mahasiswa tetapi juga sebagai tempat perkuliahan praktek mahasiswa, namun pada sisi yang lain laboratorium juga dijadikan sebagai alat untuk meningkatkan mutu kompetensi mahasiswa terutama dalam bidang layanan konseling. Menurut Badan Penjaminan Mutu Pendidikan Tinggi (BPMPT), keberadaan laboratorium memiliki fungsi yang beragam antara lain:

1. Untuk melayani masyarakat, khususnya masyarakat perguruan tinggi dalam hal media pembelajaran.

2. Sebagai tempat penyelenggaraan praktek pengajaran secara mikro bagi mahasiswa yang mengambil mata kuliah tertentu di jurusan masing-masing.

3. Sebagai tempat diskusi pembelajaran, seminar, tempat koordinasi pelaksanaan praktek kuliah lapangan serta koordinasi unit kegiatan mahasiswa yang berkaitan dengan kegiatan kampus. 
4. Sebagai pusat pengembangan mahasiswa yang berhubungan dengan kegiatan akademik, seperti pelaksanaan tugas dan kegiatan kelompok, pelaksanaan praktek mengajar dalam kelompok kecil (micro teaching), pelaksanaan kuliah dalam kelas kecil, pelaksanaan praktek dan uji studi lapangan dan lain sebagainya.

Laboratorium yang bermutu yaitu laboratorium yang mampu dikelola dengan sebaik-baiknya, baik oleh kepala laboratorium, laboran maupun stake holder yang menggunakan laboratorium tersebut. Pengelolaan yaitu suatu kegiatan menggerakkan sekelompok orang (SDM), keuangan, peralatan fasilitas, dan atau segala objek lainnya secara efektif dan efisien untuk mencapai tujuan atau sasaran tertentu yang diharapkan secara optimal. Dalam konteks laboratorium, pengelolaan meliputi beberapa aspek yaitu aspek perencanaan, penataan, pengadministrasian, pengamanan, perawatan dan pengawasan (Arthur J. Jones dalm Sofyan S. Willis, 2004).

\section{PEMBAHASAN}

\section{A. Pentingnya Laboratorium Konseling bagi Mahasiswa Jurusan BKI}

Berdasarkan hasil hasil wawancara dengan beberapa informan mahasiswa Jurusan BKI memberikan harapan bagi mahasiswa BKI bahwa secara keseluruhan saat ini mahasiswa sangat membutuhkan adanya laboratorium konseling BKI, dengan berbagai alasan pentingnya sebagai berikut:

1. Mahasiswa BKI masih lebih banyak mendapatkan pengetahuan mata kuliah secara teoritis.

2. Mahasiswa BKI belum banyak melakukan praktik konseling secara langsung baik di dalam kampus maupun di luar kampus.

3. Mahasiswa BKI merasa belum maksimal dalam kompetensi yang dimilikinya.

4. Mahasiswa BKI merasakan sangat minimnya sarana prasarana penunjang pembelajaran di Jurusan BKI.

5. Mahasiswa Jurusan BKI mengharapkan profil lulusan mahasiswa BKI semakin diperjelas, seperti ketika mahasiswa BKI ingin menjadi seorang penyuluh, konselor, terapis, rohis dan pekerja sosial, maka harus ada mata kuliah yang mendukung ke arah profil lulusan tersebut secara khusus.

6. Mahasiswa BKI mengharapkan agar semua mahasiswa dapat memahami dan menguasai berbagai konsep dan pendekatan Bimbingan dan Konseling Islam, serta memiliki kapasitas intelektual untuk memahami masalahmasalah psikologis individu, kelompok (komunitas) dan masyarakat luas.

7. Mahasiswa BKI mengharapkan agar mampu mengidentifikasi dan menyelesaikan masalah-masalah psikologi dalam keluarga dan masyarakat, melalui penyelenggaraan bimbingan dan konseling Islam, pemberian motivasi dan pelatihan, serta tindakan mediasi dan advokasi. 
8. Mahasiswa merasa bahwa antara pimpinan Jurusan, Fakultas dan dosen BKI belum adanya kekompakkan dalam memajukkan Jurusan BKI.

9. Dosen-dosen yang mengajar di Jurusan BKI masih lebih banyak menggunakan strategi ceramah dan diskusi dibandingkan melakukan praktek, pengamatan dan observasi.

10. Belum ada ruang praktek yang refresentatif bagi dosen BKI dalam mempraktekkan komunikasi konseling kepada mahasiswa.

Dengan melihat berbagai alasan dan pertimbangan di atas, maka keberadaan laboratorium konseling bagi mahasiswa BKI sangat penting dan sangat dibutuhkan dalam meningkatkan skill mahasiswa dalam melaksanakan bimbingan, konseling dan psikoterapi. Selanjutnya hasil wawancara dengan informan terkait dengan pelayanan praktek konseling, responden menilai bahwa praktek konseling yang dilaksanakan di jurusan BKI masih sangat minim, termasuk juga dalam hal meningkatkan skill dan kompetensi mahasiswa, saat ini mengindikasikan bahwa praktek konseling yang dilakukan mahasiswa saat ini masih belum memuaskan. Begitu pula terkait dengan aspek sarana prasarana yang diberikan lembaga kepada mahasiswa jurusan BKI belum memadai dan belum refresentatif dalam memaksimalkan kompetensi mahasiswa.

Selanjutnya dalam aspek kapasitas dosen dan kemampuan dosen dalam memberikan praktek konseling, tingkat kepuasan mahasiswa dalam menilai dosen terutama dalam hal pelaksanaan praktek konseling masih jauh dari harapan mahasiswa. Kondisi ini mungkin disebabkan karena jumlah dosen praktisi dalam bidang konseling masih sangat sedikit. Ketersediaan dosen-dosen yang ada dan mengajar di jurusan BKI masih lebih banyak memberikan pengetahuan teoritis dibandingkan dengan kemampuan praktis.

Selain itu pentingnya laboratorium konseling BKI dalam memaksimalkan kompetensi mahasiswa harus berangkat dari profil lulusan jurusan BKI. Perumusan kompetensi lulusan merupakan tahap awal setelah ditentukan profil lulusan. Penentuan kompetensi lulusan merupakan titik tolak dalam menentukan kelancaran dan keberhasilan mahasiswa di dalam kegiatan perkuliahan (Casmini, 2014).

Sesuai dengan harapan dari kurikulum KKNI bahwa profil lulusan ditentukan oleh pasar atau dunia kerja yang akan menerima alumni bekerja di perusahaan, instant atau lembaga masyarakat tersebut. Oleh karena itu, peninjauan kembali kurikulum yang ada di jurusan BKI pun mutlak harus mengalami revisi secara total agar kurikulum yang ada dapat disesuaikan dengan kebutuhan lapangan pekerjaan.

\section{B. Profil Kompetensi Mahasiswa Jurusan Bimbingan Konseling Islam (BKI)}

Jurusan Bimbingan Konseling Islam IAIN Syekh Nurjati Cirebon sudah berdiri sejak tahun 2011, dengan visinya yaitu "Menjadi Jurusan yang unggul 
dan terkemuka dalam menghasilkan tenaga profesional dalam bidang Bimbingan dan Konseling Islam (BKI)". Dan dengan misinya sebagai berikut :

1. Menyelenggarakan pendidikan dan pembelajaran BKI dengan ilmu terkait sebagai proses penyiapan konselor Islam profesional

2. Mengembangkan penelitian BKI untk kepentingan akademik dan masyarakat

3. Meningkatkan peran serta dalam upaya membantu menyelesaikan persoalan individu pendidikan dan keluarga

4. Memperluas kerjasama dengan berbagai pihak untuk meningkatkan pelaksanaan tri darma Perguruan Tinggi (Borang Akreditasi Jurusan BKI, 2014).

Sedangkan tujuan di dirikannya Jurusan BKI antara lain meliputi tujuan umum dan tujuan khusus. Tujuan Umumnya yaitu dalam rangka mendidik calon cendekiawan muslim yang beriman, bertaqwa dan berakhlak mulia serta memiliki kealian dan keterampilan sebagai sarjana dakwah dalam bidang Konseling dan Bimbingan Islam. Sedangkan tujuan khususnya yaitu bertujuan untuk menghasilkan sarjana yang memiliki keahlian akademik, keahlian teoritik dan keahlian praktik di bidang bimbingan konseling, penyuluhan dan psikoterapi Islam dengan bentuk kompetensi sebagai:

1. Pembimbing dan konselor agama di lembaga pemerintahan maupun masyarakat;

2. Pembimbing dan konselor pendidikan di Madrasah, Pesantren maupun sekolah;

3. Pembimbing karir Islam di Lembaga Pendidikan dan perusahaan;

4. Pembimbing dan konselor pra nikah dan keluarga sakinah di Kemenag/BP4;

5. Pembimbing dan konselor mental rohani (BIMTAL/BOMROH) di Dephankam, Kepolisian, Lembaga Pemasyarakatan;

6. Pembimbing rohani Islam di Rumah Sakit;

7. Penyuluh agama di Kemenag;

8. Penyuluh keluarga berencana di BKKBN;

9. Penyuluh anti narkoba (Penyuluh Sosial di BNN/BNP);

10. Penyuluh sosial di Kemensos;

11. Terapis/pendamping dengan basis psikoterapi religius pada berbagai lembaga terapi;

12. Ilmuwan/akademisi dakwah (dosen/peneliti) bidang bimbingan konseling, penyuluhan dan psikoterapi Islam (Borang Akreditasi BKI, 2014).

Adapun kompetensi yang akan di raih oleh mahasiswa Jurusan BKI nantinya, yaitu mahasiswa diharapkan memiliki kompetensi utama sebagai berikut:

1. Landasan Kepribadian (Karakter) 
a. Menjadi manusia yang beriman dan bertaqwa kepada Tuhan Ynag Maha Esa, berbudi luhur, berkepribadian, berdisiplin, bekerja keras, tangguh, bertanggung jawab, mandiri, cerdas dan trampil serta sehat jasmani dan rohani;

b. Memiliki kompetensi kepribadian, yaitu kemampuan kepribadian yang mantap, berakhlah mulia, arif, dan berwibawa serta menjadi teladan mad'u/jamaah;

c. Menumbuhkan dan memperdalam rasa cinta tanah air, mempertebal semangat kebangsaan dan rasa kesetiakawanan sosial; dan

d. Menumbuhkan rasa percaya diri sendiri serta bersikap dan berprilaku yang inovatif dan kreatif.

2. Penguasaan Ilmu dan Keterampilan

a. Terampil dan mampu menguasai bidang Bimbingan dan Konseling Islam berbasis kompetensi;

b. Terampil dalam penguasaan metode dan penerapan keilmuan pengembangan masyarakat sesuai dengan perkembangan dan kebutuhan;

c. Terampil merancang program intervensi komunitas yang berbasis kompetensi;

d. Mampu memadukan ilmu, agama, dan nilai menjadi satu kesatuan pemikiran dan tindakan yang menjadi kontribusi dalam mengembangkan dan memajukan masyarakat serta ilmu pengetahuan;

e. Bersikap terbuka dan tanggap terhadap perubahan dan kemajuan ilmu berkaitan dengan masalah yang dihadapi masyarakat; dan

f. Memiliki kemampuan untuk melanjutkan pendidikan pada strata yang lebih tinggi.

3. Kemampuan Berkarya

a. Menguasai ilmu pengembangan masyarakat yang menunjang terhadap sistem, instrumen, dan perencanaan program perubahan sosial ke arah yang lebih baik;

b. Memiliki kemampuan untuk menjadi agen perubahan bagi masyarakat sekitarnya;

c. Memiliki kompetensi profesional, yaitu kemampuan penguasaan materimateri dan metode-metode pengembangan masyarakat secara luas dan mendalam; dan

d. Mampu bekerja secara profesional di bidang pengembangan masyarakat.

4. Sikap dan Perilaku dalam Berkarya Menurut Tingkat Keahlian Berdasarkan Ilmu dan Keterampilan yang dikuasai.

a. Memahami, menghayati dan mengamalkan kode etik ilmu dan nilai keilmuan dan penelitian;

b. Mampu berkomunikasi secara efektif dan bekerjasama dalam mengembangkan fungsi perannya dalam sebuah tim yang multi disiplin;

c. Keterbukaan sikap untuk selalu melakukan perbaikan secara berkesinambungan; 
d. Memiliki sikap profesionalisme dan etika moral profesi yang tinggi;

e. Memiliki kompetensi sosial, yaitu kemampuan untuk berinteraksi secara efektif dan efisien dengan masyarakat;

f. Memiliki pengetahuan mengenai profesi bidang pengembangan masyarakat dalam masyarakat;

g. Mampu memahami dan ikut berperan serta dalam menyelesaikan fenomena yang terjadi di masyarakat berdasarkan ilmu pengembangan masyarakat;

h. Mampu mengabdikan ilmu pengembangan masyarakat dalam membantu komunitas untuk memecahkan permasalahan sosial (Wakhit Hasyim, dkk, 2014).

Rumusan kompetensi yang berdasarkan profil lulusan BKI harus memperhatikan values (lembaga), scientific vision (jurusan) dan market signal (stake holder dan alumni) (Casmini, 2014).

Beberapa contoh rumusan kompetensi yang harus dimiliki oleh mahasiswa BKI adalah sebagai berikut.

a. Mahasiswa mampu mengidentifikasi masalah yang terjadi di masyarakat.

b. Mahasiswa mampu menyelenggarakan kegiatan konseling bagi masyarakat.

c. Mahasiswa mampu menyelesaikan masalah yang dihadapi masyarakat.

d. Mahasiswa mampu menguasai berbagai pendekatan konseling.

e. Mahasiswa mampu memberikan motivasi dan pelatihan kepada masyarakat.

f. Mahasiswa mampu melakukan mediasi dan advokasi.

g. Mahasiswa mampu menguasi teori-teori psikologi dan teori pendidikan.

h. Mahasiswa mampu mengidentifikasi dan menyelesaikan masalah yang dihadapi peserta didik.

i. Mahasiswa mampu memberikan layanan BKI di lembaga pendidikan dan pondok pesantren.

j. Mahasiswa mampu merencanakan dan melaksanakan evaluasi BKI.

k. Mahasiswa mampu membimbing dalam bidang pribadi, agama, sosial, belajar dan karir.

1. Mahasiswa mampu menunjukkan kinerja akademik dan profesionalisme dalam bidang BKI.

m. Mahasiswa mampu memahami keragaman individu dan masyarakat.

n. Mahasiswa mampu menguasai manajemen BKI di masyarakat.

o. Mahasiswa mampu menguasai perkembangan dan kepribadian individu.

p. Mahasiswa mampu memanfaatkan berbagai media BKI.

q. Mahasiswa mampu menguasai manajemen pelatihan dan teknik-teknik motivasi.

r. Mahasiswa mampu menguasai prinsip-prinsip komunikasi interpersonal.

s. Mahasiswa mampu mengembangkan ilmu pengetahuan dan teknologi BKI. 
t. Mahasiswa mampu menguasai manajemen konflik dan manajemen intervensi.

u. Mahasiswa mampu menguasai dasar-dasar keilmuan dakwah.

v. Mahasiswa mampu mengembangkan penerapan konseling, motivasi dan pelatihan dalam berbagai kehidupan.

w. Mahasiswa mampu memberikan ceramah, bimbingan dan penyuluhan kepada masyarakat.

x. Mahasiswa mampu melakukan terapi dan rehabilitasi kepada klien yang bermasalah dan beresiko tinggi.

y. Mahasiswa mampu mengembangkan konsep-konsep filosofis dan teoritis dalam bidang psikologi dan bimbingan konseling.

Itulah pentingnya laboratorium konseling BKI dalam memaksimalkan kompetensi mahasiswa BKI dengan berbagai rumusan kompetensi yang harus dicapai oleh seluruh mahasiswa BKI. Apabila semua mahasiswa BKI sudah memiliki kompetensi seperti di atas, maka mahasiswa akan jauh lebih siap terjun pada dunia kerja sesuai dengan kebutuhan stakeholder yaitu untuk bekerja dalam bidang konselor Islam pada BP4, LP (Lembaga Pemasyarakatan), Rumah sakit, Dinas Sosial, BNN, pusat terapi dan rehabilitasi, guru BK, aktifis LSM, dan penyuluh agama.

\section{Laboratorium Konseling untuk Mahasiswa Jurusan BKI IAIN Syekh Nurjati Cirebon}

Profesionalitas mahasiswa Jurusan Bimbingan Konseling Islam (BKI), lebih difikuskankan pada pengembangkan ilmu konseling, penyuluhan dan psikoterapi, yang didasari oleh nilai-nilai keislaman sesuai dengan kebutuhan hidup manusia. Maka kompetensi yang harus dimaksimalkan agar dapat mencapai tujuan tersebut adalah bidang keahlian konselor, baik iu di sekolah, masyarakat, lembaga, di dalam menangani masalah-masalah manusia baik yang menyangkut masalah pribadi, problem rumah tangga dan keluarga, masalah sosial kemasyarakatan, dan masalah perkembangan siswa di sekolah.

Untuk memaksimalkan kompetensi yang harus dikuasai mahasiswa lulusan jurusan BKI tersebut tentunya membutuhkan dukungan fasilitas sarana dan prasarana pendidikan yang memadai, salah satunya adalah laboratorium (A, Said Hasan Basri, 2014: 108). Jurusan Bimbingan Konseling Islam, sebagai bagian terkecil dari sebuah perguruan tinggi sudah seyogyanya memiliki laboratorium yang ideal dan relevan dengan keilmuannya. Sesuai dengan tujuan diselanggarakannya laboratorium BKI, bahwa laboratorium harus dijadikan sebagai tempat praktek pengembangan keilmuan (bengkel kerja) bagi mahasiswa sesuai dengan profil lulusan kerjanya.

Selain itu, laboratorium konseling juga dapat berfungsi sebagai tempat diskusi pembelajaran, seminar mahasiswa, tempat koordinasi pelaksanaan praktikum dan praktek kuliah lapangan serta sebagai media koordinasi antara 
unit kegiatan mahasiswa dengan seluruh kegiatan yang ada di kampus. Laboratorium yang ideal bagi mahasiswa Jurusan Bimbingan Konseling Islam terutama peranannya dalam memaksimalkan kompetensi mahasiswa BKI, antara lain melalui pengembangan laboratorium sebagai berikut.

\section{Laboratorium Terpadu}

Laboratorium terpadu adalah laboratorium yang secara sistem pengelolaanya dibawah langsung naungan Fakultas Ushuluddin Adab Dakwah yang nantinya apabila terpisah sendiri Fakultas Dakwahnya, maka posisi laboratorium ini berada di bawah naungan Fakultas Dakwah. Laboratorium terpadu ini, dapat dikatakan sebagai laboratorium pusat dan semua civitas akademika yang berada di Fakultas Dakwah dapat memanfaatkannya dan menggunakan fasilitas ini.

Model laboratorium terpadu yang ideal untuk Jurusan BKI paling tidak sedikitnya memiliki delapan ruangan khusus dengan penggunaan alokasi ruangan antara lain ; satu ruangan untuk para petugas laboran dan tenaga kesekretariatan, satu ruangan untuk aula (tempat pelatihan dan diskusi), satu ruangan sebagai tempat riset dan pengembangan, satu ruangan untuk penyimpanan peralatan dan instrumen, kemudian satu ruangan sebagai gudang persediaan, penyimpanan arsip dan segala macam, serta tiga ruangan lainnya yaitu untuk laboratorium masing-masing jurusan (KPI, PMI BKI). Ruangan di laboratorium ini perlu dilengkapi dengan pengeras suara, komputrer, Ac, ketersediaan Dispenser Air Minum, lampu listrik yang terang, meja tulis dan kursi secukupnya, lemari kantor dan administrasi, hotspot area, serta papan tulis yang refresentatif.

Model laboratorium terpadu untuk ketiga jurusan tersebut (KPI, PMI, BKI) harus memiliki ukuran yang cukup besar paling tidak sama ukurannya dengan ukuran ruang kuliah, dengan masing-masing laboratorium memiliki sekat-sekat untuk ruangan yang lainnya. Misalnya seperti; ada ruangan khusus untuk administrasi, ruangan tempat dokumentasi dan perpustakaan mini, ruangan praktek, serta ruangan fublik apabila jurusan tersebut membuka lahan khusus untuk layanan publik kepada masyarakat.

Adapun unsur-unsur yang harus ada pada laboratorium terpadu ini meliputi:

a. Organisasi Laboratorium Terpadu: Struktur organisasi pada laboratorium terpadu secara hierarki dipimpin langsung oleh Dekan Fakultas secara langsung, dengan mengangkat seorang dosen sebagai ketua pelaksananya dan satu orang sekretaris. Selanjutnya di dalam struktur tersebut dipilih koordinator divisi-divisi tersendiri seperti divisi komunikasi dan penyiaran Islam, divisi pengembangan masyarakat Islam dan divisi konseling Islam.

b. Fasilitas sarana dan prasarana laboratorium terpadu: Sebagai penunjang utama terlaksananya laboratorium terpadu yakni harus tersedianya sarana prasarana yang memadai baik itu unutuk jurusan KPI, PMI, maupun BKI. Paling tidak sarana yang dibutuhkan tersebut antara lain: Televisi, Radio, 
Studio Fotografi, Studio Computer Editing, Multimedia, Lab Micro Conseling, dan Lab Pengembangan Masyarakat Islam.

c. Administrasi Laboratorium Terpadu: Penataan administrasi pada laboratorium terpadu terkoordinasi di bawah naungan fakultas dengan memuat ketentuan dan prosedur penggunaannya. Ketentuan dan prosedur penggunaan laboratorium terpadu nantinya terkait dengan penggunaan lab secara rutin di antaranya yaitu jenis pratikum yang dilaksanakan antara lain terkait dengan jurusan masing-masing seperti Komunikasi Penyiaran Islam, Pengembangan Masyarakat Islam dan Jurusan Bimbingan Konseling Islam,

d. Kelembagaan praktikum adalah kegiatan praktikum satu mata kuliah yang dikelola oleh dosen yang mengampu mata kuliah praktik yang diangkat berdasarkan SK dari Fakultas.

e. Layanan masyarakat adalah pemberian layanan kepada masyarakat dalam bentuk informasi dakwah dan informasi terkait jurusan masing-masing (Rina, 2011).

\section{Laboratorium Konseling BKI}

Laboratorium Konseling BKI adalah laboratorium yang pengelolaannya berada di bawah koordinasi dan kewenangan Jurusan BKI. Laboratorium Konseling Jurusan BKI, diproyeksikan untuk memfasilitasi mahasiswa dan dosen dalam melaksanakan kegiatan ilmiah terkait dengan mata kuliah praktik bimbingan konseling Islam. Misalnya seperti kegiatan praktikum, pelatihan, penelitian, diskusi, pelayanan konseling dan kegiatan-kegiatan lainnya yang dapat membantu mahasiswa dalam memaksimlkan kompetensinya.

Ruangan laboratorium konseling yang cukup ideal dilaksanakan oleh Jurusan BKI, minimalnya memiliki bagian-bagian secara terpisah, seperti: adanya front office, ruang konseling individu, ruang konseling kelompok, ruang tamu, ruang kantor, dan ruang penataan administrasi seperti lemari tempat arsip dan dokumentasi.

Selain itu, laboratorium konseling yang ideal paling tidak harus memenuhi beberapa komponen dasar antara lain: adanya organisasi laboratorium, adanya pengadministrasian laboratorium, adanya fasilitas sarana dan prasarana yang memadai, dan adanya prosedur penggunaan laboratorium.

Model laboratorium Konseling yang ideal bagi jurusan BKI, harus memiliki keunikan dan karakteristik yang berbeda dengan jurusan yang lainnya, apalagi karakateristik itu juga melekat pada visi dan misi dari Jurusan itu sendiri. Sesuai dengan tujuan dari jurusan BKI yaitu dalam rangka mencetak SDM yang unggul dalam ilmu-ilmu keislaman dan menyiapkan calon sarjana yang beriman, beraklak, serta memiliki kemampuan secara professional dalam bidang konseling Islam. Maka kompetensi yang harus dimiliki oleh seluruh mahasiswa BKI adalah mahasiswa harus memiliki kompetensi khusus dalam bidang konselor Islam pada BP4, LP (Lembaga Pemasyaraatan), Rumah sakit, pusat rehabilitasi, BNN, Dinas Sosial, LSM, Sekolah / Guru BK, dan penyuluh agama. 
Secara struktural laboratorium BKI nantinya terdiri dari: pengarah/penanggung jawab, ketua, dan divisi-divisi yang berada di bawahnya, secara skema dapat digambarkan sebagai berikut :

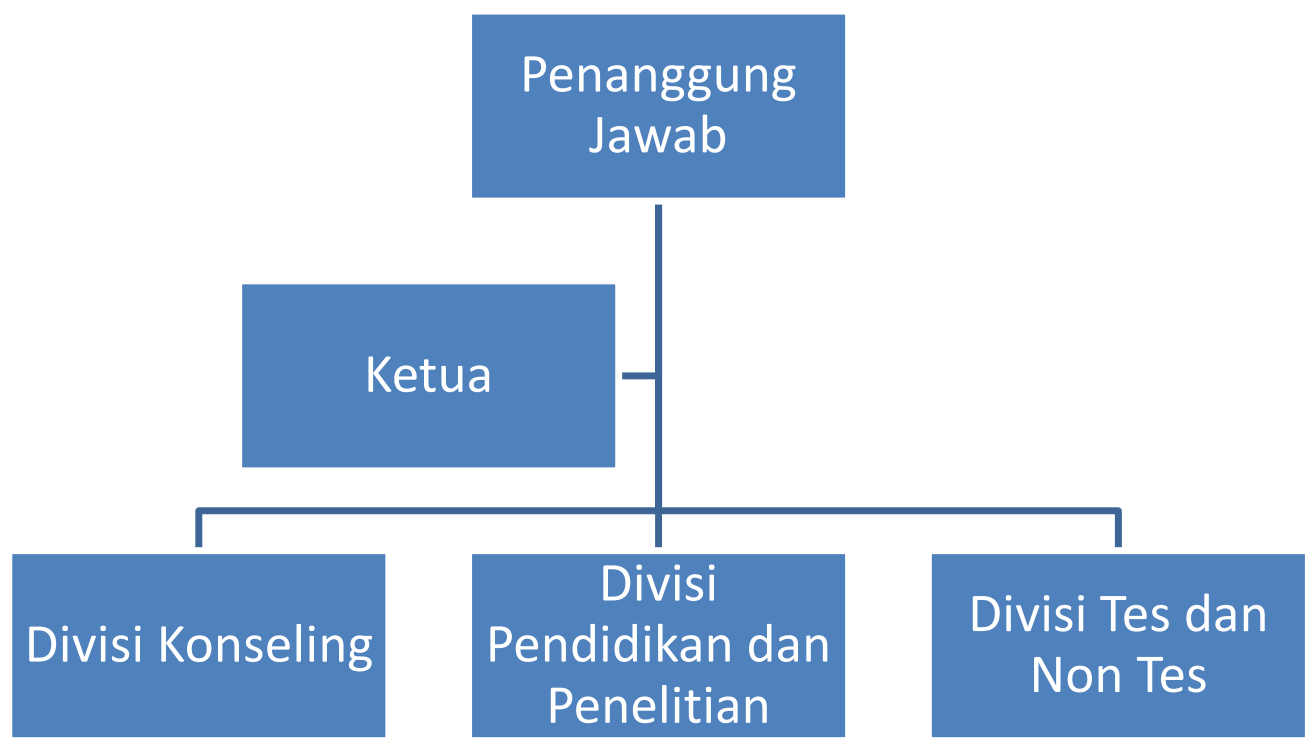

Masing-masing tugas atau job description dari masing-masing divisi dapat dirumuskan sebagai berikut:

a. Divisi Konseling, divisi ini memiliki tugas dalam pelaksanaan pelayanan mikro konseling bagi mahasiswa, serta pemberian layanan konseling bagi mahasiswa non BKI dan masyarakat lainnya. Peran utama dari divisi ini adalah memfungsikan lab sebagai klinik, terapi atau biro konseling terutama dalam menangani berbagai permasalahan individu, masalah perkembangan anak dan remaja, dan masalah sosial kemasyarakatan.

b. Divisi Pendidikan dan Penelitian, pada divisi ini yang menjadi fokus utama adalah mahasiswa BKI khususnya dalam memberikan pendidikan dan pelatihan keterampilan konselor kepada seluruh mahasiswa BKI terutama kepada mahasiswa yang akan melaksanakan praktek pengalaman lapangan (PPL). Selain itu tugas lainnya adalah mengadakan berbagai pelatihan kepada mahasiswa baik itu leadership, enterprneurship, trainer motivator, ataupun kegiatan lainnya seperti diskusi dan penyuluhan agama. Dalam aspek penelitian, divisi ini dapat dimanfaatkan sebagai pengelola hasil-hasil penelitian mahasiswa dan dosen baik itu dalam bentuk artikel ke media maupun dalam bentuk jurnal.

c. Divisi Tes dan Non Tes, pada divisi ini tugas utamanya adalah memfasilitasi mahasiswa dalam berbagai kebutuhan alat-alat tes maupun non tes dalam bentuk instrumen ataupun assesmen. Selain itu, dapat memfasilitasi juga alat-alat tes psikologi seperti alat tes IQ, tes kepribadian, tes komunikasi efektif dan berbagai alat tes lainnya. 


\section{Laboratorium Lapangan Berbasis Institusi dan Masyarakat}

Laboratorium lapangan berbasis institusi dan masyarakat adalah lokasi tempat praktek atau tugas lapangan berupa kerjasama pengabdian maupun penelitian antara mahasiswa jurusan BKI dengan stakeholder masyarakat yang menjadi lahan mahasiswa dalam melakukan praktik konseling, penelitian dan pengabdian. Lokasi ini dapat dikategorikan sebagai laboratorium lapangan berbasis masyarakat marena menjadi tempat mahasiswa untuk melakukan observasi, praktik, pengabdian dan penelitian (A. Said Hasan Basri, 2014).

Bentuk dari laboratorium lapangan ini merupakan implementasi dari mata kuliah yang bermuatan praktik yang biasanya bentuknya observasi, kerjasama, pengabdian dan penelitian. Observasi dan kerjasama biasanya berupa tugas mata kuliah tertentu dengan menawarkan sesuatu dan menerapkan sesuatu yang ada dalam teori perkuliahan. Sedangkan penelitan, biasanya berupa observasi dan wawancara dari beberapa mata kuliah praktik maupun mata kuliah skripsi sebagai tugas akhir mahasiswa. Tugas akhir mahasiswa lainnya juga antara lain yaitu mahasiswa wajib melaksanakan Kuliah Kerja Nyata (KKN) dan melaksanakan Praktek Pengalaman Lapangan (PPL).

Adapun yang menjadi tempat praktik laboratorium lapangan berbasis masyarakat yang dapat dilaksanakan oleh mahasiswa jurusan BKI antara lain:

a. Lembaga Pendidikan dan Pesantren: Lembaga pendidikan dan pesantren yang menjadi wilayah garapan mahasiswa BKI meliputi pendidikan formal dan non formal. Pada pendidikan formal diawali dari pendidikan dasar dan menengah (SD, SMP, SMA / MI, MTs/ MA), Pendidikan Non Formal berupa pendidikan pesantren atau pusat-pusat belajar dan pendidikan masyarakat (PKBM), dan lembaga sekolah khusus seperti sekolah luar Biasa (SLB), Sekolah siswa Difabel, sekolah bagi anak-anak Autis dan Sekolah bagi anak-anak jalanan.

b. Lembaga-lembaga yang Bergerak pada layanan Publik: Lembaga yang bergerak pada layanan publik umumnya berada di bawah naungan berbagai kementerian. Misalnya KUA (Kantor Urusan Agama) dibawah naungan Kemenag, Penamas (Penyuluhan Masyarakat), Kantor Pengadilan Agama terutama dalam melakukan konsleing kepada suami istri yang akan bercerai dan lembaga-lembaga lainnya.

c. Lembaga Sosial: Lembaga sosial yang banyak berkembang di masyarakat adalah lembaga sosial yang langsung berada di bawah naungan Dinas Sosial maupun lembaga yang dikelola oleh pihak swasta, yayasan atau lembaga sosial masyarakat (LSM). Instansi atau lembaga ini banyak bergerak dalam penanganan dan penanggulangan serta pendampingan komunitas-komunitas beresiko tinggi, mengalami masalah sosial dan kesehatan mental serta kelompok-kelompok minoritas yang termarginal yang membutuhkan bantuan.

d. Lembaga Kesehatan: Lembaga kesehatan ini meliputi kesahatan fisik dan kesehatan mental. Seperti Pusat Rehabilitasi NAPZA, Pusat Rehabilitasi 
difabel, RSUD (Rumah Sakit Umum dan dan Rumah sakit Jiwa), PKBI (Perhimpunan Keluarga Berencana Indonesia) dan lembaga-lembaga lainnya yang berada pada Dinas Kesehatan.

e. Instansi atau Perusahaan: Instansi atau perusahaan, baik instansi pemerintah yang berada di bawah naungan kementerian Perdagangan dan Perindustrian maupun swasta. Contohnya seperti: home industry dan kewirausahaan, industri kecil dan menengah (UKM), industri kreatif, sampai perusahan dan industri besar.

f. Lembaga di bawah naungan Kemenkumham: Lembaga yang berada di bawah naungan Kemenkumham antara lain Lapas (Lembaga Kemasyarakatan) atau Bapas (Badan Kemasyarakatan) baik yang umum maupun untuk anak, ataupun yang khusus menangani Korupsi dan Narkoba, kemudian BNN (Badan Narkotika Nasional).

g. Masyarakat Umum: Masyarakat secara umum dapat dijadikan sebagai tempat laboratorium lapangan berbasis masyarakat apabila di dalam masyarakat tersebut memiliki keunikan atau munculnya berbagai masalah yang bersifat terstruktur. Seperti: kelompok masyarakat unggulan, dan masyarakat yang beresiko tinggi, masyarakat rawan tawuran, dan masyarakat miskin pesisir pedesaan dan masyarakat yang terkucilkan/termarginalkan.

\section{SIMPULAN}

Berdasarkan uraian yang telah dipaparkan dalam pembahasan dan analisa yang telah dilakukan peneliti, maka dapat disimpulkan bahwa:

1. Mahasiswa BKI harus memiliki laboratorium konseling bagi pengembangan kompetensi mahasiswa dan sebagai sarana dalam penguasaan keterampilan praktek konseling mahasiswa baik dalam konseling individu maupun konseling kelompok.

2. Kompetensi yang diharapkan mahasiswa dalam meningkatkan skillnya harus lebih ditingkatkan, karena ketersediaan sarana prasarana di jurusan BKI tergolong masih kurang, begitu pula dengan kapasitas kemampuan dosen dalam mempraktekkan kegiatan konseling masih sangat minim. Hal ini disebabkan karena masih sedikitnya dosen praktisi konseling yang mengajar di Jurusan Bimbingan Konseling Islam.

3. Model laboratorium yang ideal yang dapat diterapkan di Jurusan Bimbingan Konseling Islam dapat diterapkan dengan tiga model pendekatan yaitu model laboratorium terpadu yang posisinya berada di bawah naungan Fakultas Dakwah, laboratorium konseling yang berada di Jurusan BKI dan laboratorium konseling yang berbasis institusi dan masyarakat. 


\section{DAFTAR PUSTAKA}

Ali, Abdullah. (2007). Penelitian Kualitatif, Cirebon : STAIN Press, Cirebon.

Arintoko, (2011). Wawancara Konseling di Sekolah, Yogyakarta : Andi Offset, Yogyakarta.

Arthur J. Jones (Sofyan S. Willis), (2004). Konseling 1ndividual;Teori \& Praktek. Bandung: Alfaheta.

BSNP (Badan Standar Nasional Pendidikan), (2006). Panduan Penyusunan Kurikulum Tingkat Satuan Pendidikan Jenjang Pendidikan Dasar dan Menengah, Jakarta : BSNP.

BPMPT (Badan Penjaminan Mutu Pendidikan Tinggi), (2006). SOP Laboratorium. Makasar : Universitas Gorontalo.

Casmini, (2014). Evaluasi dan Peninjauan Kurikulum BKI berbasis KKNI, Yogyakarta : dalam Jurnal Hisbah, 125-143.

Hasan Basri, Said. A. (2014). Urgensi Laboratorium BKI dalam Pengembangan Kompetensi Mahasiswa, Yogyakarta : dalam Jurnal Hisbah, 99-123.

Suteja, Jaja. (2013). Bimbingan Konseling di Sekolah, Cirebon: Nurjati Press.

J. Moleong, Lexy. (2003). Penelitian Kualitatif, Bandung : Remaja Rosda Karya.

Subana, M. (2005). Dasar-dasar Penelitan Ilmiah, Bandung : Pustaka Setia.

Peraturan Pemerintah Republik Indonesia Nomor 19 tahun 2005, Tentang Standar Pendidikan Nasional

Peraturan Menteri Pendidikan Nasional No. 24 tahun 2007, Tentang Pengelolaan Laboratorium.

Peraturan Menteri Pendidikan Nasional No. 27 tahun 2008, Tentang Standar Kualifikasi Akademik dan Kompetensi Konselor.

Peraturan Menteri Pendidikan Nasional No. 63 tahun 2009, Tentang Penjaminan Mutu Pendidikan.

Rina, (2011) Manajemen Laboratorium. www. Unikal.ac.id.diakses tanggal 25 Oktober 2015.

R.M. Gagne \& Medsker K. L. 1996. The Conditions of learning: Training applications. Hartcourt Brace College: Fort Wort TX.

S. Hall Calvin, Lindzey Gardner, 1993. Psikologi Kepribadian (Teori-Teori Psikodinamik), Yogyakarta, Kanisius.

Danim, Sudarwan. (2002). Menjadi Peneliti Kualitatif. Bandung: Pustaka Setia.

Undang-undang Republik Indonesia Nomor 20 tahun 2002, Tentang Tujuan Pendidikan Nasional.

Undang-undang Republik Indonesia Nomor 20 tahun 2003, Tentang Sistem Pendidikan Nasional.

Wakhit, Hasyim, (2013). “Borang Akreditasi Jurusan Bimbingan Konseling Islam IAIN Syekh Nurjati Cirebon Tahun, 2014. Cirebon. 